\title{
Analysis of the sexual variability in the shell of the Spanish Upper Cretaceous turtle Dortoka vasconica (Pan-Pleurodira, Dortokidae)
}

\author{
Análisis de la variabilidad sexual en el caparazón de la tortuga española del Cretácico Superior Dortoka \\ vasconica (Pan-Pleurodira, Dortokidae)
}

\author{
Andrea GUERRERO (1) \& Adán PÉREZ-GARCÍA (1)
}

\begin{abstract}
The present study characterizes the morphological variability related to the sexual dimorphism in the shells of the Spanish Upper Cretaceous turtle Dortoka vasconica. This study is based on the material from its type locality: Laño, Burgos. Two morphotypes were identified there based on the posterior plastral area as well as two for the anterior plastral lobe. However, a correlation with the previously indicated morphotypes could not be established due to the disarticulation of the specimens and the limited information available on the sexual dimorphism of Pleurodira. The morphological variability previously identified for Dortoka vasconica is analysed here through a quantitative approach to evaluate the role that sexual dimorphism plays in the plastron. Comparative material of the main extinct and extant groups of pleurodires is included in this study. The results evidenced a noticeable sexual dimorphism in the anal notch of Dortoka vasconica. Likewise, the comparison of species belonging to several pleurodiran clades shows a wide range of variability in the direction and magnitude of the sexual dimorphism. Thus, a single evolutionary trend cannot be recognized, so that previous assumptions about which morphotype corresponds to each sexual dimorph in some extinct taxa and especially lineages (including basal panpleurodires) cannot be confirmed.
\end{abstract}

Resumen: El presente estudio caracteriza la variabilidad morfológica relacionada con el dimorfismo sexual en los caparazones de la tortuga española del Cretácico Superior Dortoka vasconica. Este estudio se basa en el material de su localidad tipo: Laño, Burgos. Allí, dos morfotipos fueron identificados en la región plastral posterior, y dos distintos en la región anterior. No obstante, no se pudo establecer una correlación con dichos morfotipos debido a la desarticulación de los especímenes, así como por la limitada información disponible sobre el dimorfismo sexual en Pleurodira. La variabilidad morfológica previamente identificada en Dortoka vasconica se analiza aquí cuantitativamente para evaluar el papel que juega el dimorfismo sexual en el plastrón. Además, se incluye material comparativo de los principales grupos de pleurodiras extintos y actuales. Los resultados evidencian un marcado dimorfismo sexual en la escotadura anal de Dortoka vasconica. La comparación de especies de diversos clados de pleurodiras muestra un amplio rango de variabilidad en la dirección y magnitud del dimorfismo sexual. Por ello, no se puede reconocer una única tendencia evolutiva, en consecuencia, no se pueden confirmar las suposiciones anteriores sobre qué morfotipo corresponde a cada dimorfo sexual en algunos taxones extintos y especialmente en linajes (incluidos los de pan-pleurodiras basales).
Received: 30 March 2021

Accepted: 4 June 2021

Published online: 5 July 2021

Corresponding author:

Andrea Guerrero

guerbach@gmail.com

\section{Keywords:}

Testudinata

Basal pan-pleurodires

Late Campanian-early

Maastrichtian

Sexual dimorphs

Geometric morphometric
Palabras-clave:
Testudinata
Pan-pleurodiras basales
Campaniense tardio-
Maastrichtiense temprano
Dimorfos sexuales
Morfometría geométrica

\section{INTRODUCTION}

Dortokidae is a poorly represented group of freshwater turtles restricted to the Lower Cretaceous (Barremian) to Paleocene (Thanetian) of Europe (see Pérez-García, 2017 and references therein). This clade is exclusively known by postcranial remains, which has not allowed to know its precise phylogenetic position. However, it is considered as one of the few clades of the stem group of the successful lineage of Pan-Pleurodira (Cadena \& Joyce, 2015), which still forms part of our current biodiversity (Vetter \& Thomson, 2007; Vetter, 2011; Van Dijk et al., 2014). Despite the relatively wide temporal distribution known for Dortokidae, only three taxa are currently recognized: the Spanish Barremian Eodortoka morellana Pérez-García, Gasulla \& Ortega, 2014, the Spanish Campanian-early Maastrichtian Dortoka vasconica Lapparent de Broin \& Murelaga, 1996, and the Romanian Thanetian Ronella botanica Lapparent de Broin in Gheerbrant et al., 1999 (see Pérez-García,

(C) The Author(s) 2021. This is an open-access article distributed under the terms of the Creative Commons Attribution 4.0 International License (for details please see http://creativecommons.org/licenses/by/4.0/), which permits use, copy, adaptation, distribution, and reproduction in any medium or format, as long as you give appropriate credit to the original author(s) and the source. 
2017 and references therein). The type species of Dortokidae, $D$. vasconica, is by far the taxon with a greater number of specimens of this lineage and one of the best-represented basal forms of Pan-Pleurodira worldwide (Lapparent de Broin \& Murelaga, 1996; Pérez-García et al., 2012). Outside its type locality, the presence of this species has only been confirmed in the Spanish Campanian site of Armuña (Segovia), through a few disarticulated remains (Pérez-García et al., 2016). Thus, after the original description of $D$. vasconica (Lapparent de Broin \& Murelaga, 1996), the posterior study performed on the abundant remains from its type locality (Laño, Treviño County, Burgos; late Campanian-early Maastrichtian; Pereda Suberbiola et al., 2015), significantly improved the knowledge regarding its anatomy and palaeoecology (PérezGarcía et al., 2012). As a result, two morphotypes were recognized for the anterior region of its plastron, as well as two for the posterior plastral area. However, the correlation between each of them could not be made due to the lack of articulated specimens preserving both regions. In the literature, the variation in the morphology of both regions for Pan-Pleurodira, and especially that of the posterior plastral lobe, has generally been associated with sexual dimorphism (Jiménez-Fuentes, 2007; Pritchard, 2008; Cadena et al., 2013; Limaverde et al., 2020). However, the limited information currently available due to the scarce detailed studies carried out on extant pleurodiran forms and, especially, the limited and poorly justified assumptions made for extinct pleurodires, has not allowed, until now, its justified analysis in basal forms such as $D$. vasconica.

In this context, the main objective of this study is to characterize the morphological variability which could be related to the sexual dimorphism in the shell of $D$. vasconica. To achieve it, a comparative framework is established between various representatives of the pleurodiran lineages that are part of the current biodiversity. In this way, previous hypotheses (e.g., the use of the most posterior plate of the ventral surface of the shell, the xiphiplastron, as the main character for sexing extinct pan-pleurodiran taxa or the attribution of morphotypes to specific sexes) on various species of basal and derived Pan-Pleurodira can be revaluated.

Institutional abbreviations. ALG, Algora collection, deposited in the Museo de Paleontología de Castilla-La Mancha, Cuenca, Spain; BSP, Bayerischen Staatssammlung für Paläontologie und Geologie, Munich, Germany; DGM/DNPM, Divisão de Geologia e Mineralogia, Museu de Ciências da Terra, Departamento Nacional da Produção Mineral, Rio de Janeiro, Brazil; IPN-EAC, Museo Geológico José Royo y Goméz-Instituto Colombiano de Geología y Minería-Ingeominas, Bogotá, Colombia; LP-UFC, Laboratório de Paleontologia, Universidade Federal do Ceará, Fortaleza, Brazil; MCNA, Museo de Ciencias Naturales de Alava, Vitoria-Gasteiz, Spain; MN, Museu Nacional, Universidade Federal do Rio de Janeiro, Rio de Janeiro, Brazil; MNHN.RA,
Collection of Reptiles et Amphibiens, Muséum national d'Histoire naturelle, Paris, France; MNHN.ZA.AC, Collection of Reptiles, Comparative Anatomy, Muséum national d'Histoire naturelle, Paris, France; MPSC, Museu de Paleontologia de Santana do Cariri, Santana do Cariri, Brazil; NMS, Naturmuseum Solothurn, Solothurn, Switzerland; STUS, Sala de las Tortugas de la Universidad de Salamanca, Salamanca, Spain.

\section{MATERIALS AND METHODS}

\section{Materials}

A sample of 45 specimens of Dortoka vasconica are evaluated here, which 16 correspond to disarticulated xiphiplastra (see section S1 of the Supplementary Information for more details), and 3 to articulated (MCNA $6313,7404,14331$ ) and 26 to disarticulated (L1A95245, L1A95-289, L1A95-1005, L1A95-1007, L1A97254.2, L1A97-264, L1A97-1206, MCNA 6341, 6550, $6555,6559,6591,6718,6726,6769,6815,6856,6871$, $6878,6921,6922,6959,6966,14329,14330,14332)$ elements of the anterior plastral lobe. The minimum number of individuals is 16 taken into account the xiphiplastra. The xiphiplastra correspond to previously described and figured specimens (Fig. 1B, 1D, 1E, 1F, 1H-L, 1P; see Lapparent de Broin \& Murelaga, 1996, 1999; Lapparent de Broin et al., 2004; Pérez-García et al., 2012), as well as to unpublished ones (Fig. 1A, 1C, $1 \mathrm{G}, 1 \mathrm{M}, 1 \mathrm{~N}, 1 \mathrm{O})$.

In this study, the two morphotypes of the anterior plastral lobe established by Pérez-García et al. (2012) have not been included in either the quantitative or qualitative approaches, due to the lack of more specific information in the comparative material of the extant representatives, as well as due to the sample size of $D$. vasconica. Specifically, in the first case, there are no detailed studies that demonstrate that exists a significant sexual variation in this region in extant pleurodiran clades. Likewise, the sample size available here for each species of the extant representatives does not allow us a proper characterization to make new inferences regarding the sexual variation on the anterior lobe. In regard to the sample size, this is not enough to carry out the analysis through a quantitative approach. The previous morphotypes identified in this region are based on the entire lobe (i.e., the morphology of several plates, the arrangement of the scutes as well as the general contour of the anterior plastral lobe). Therefore, it would be necessary analyse the whole set of anterior plastral elements. If so, the number of required variables would be much greater than the sample number available, which would affect the statistic power of the analyses.

\section{Methods}

Qualitative and quantitative approach. Both qualitative and quantitative approaches were performed in this study to evaluate the role that the sexual dimorphism 
A

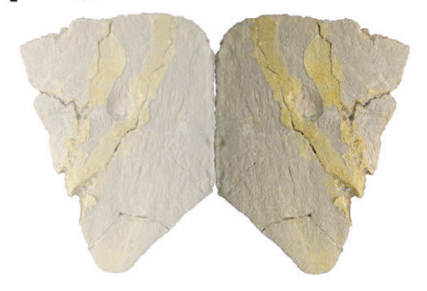

D

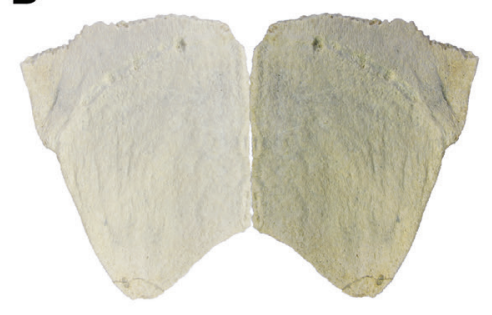

G

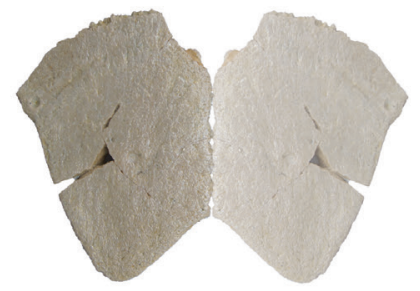

J

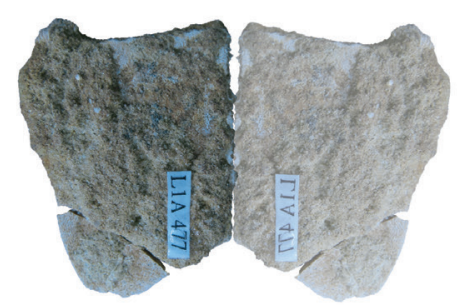

B

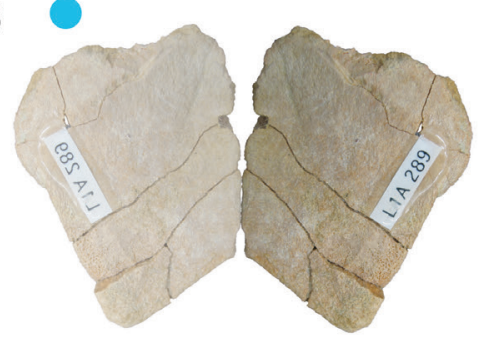

E

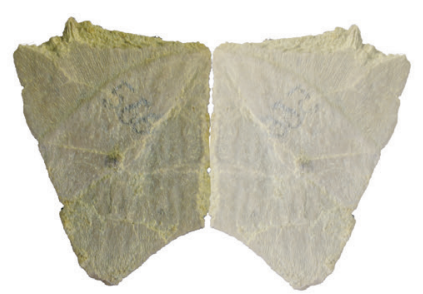

H

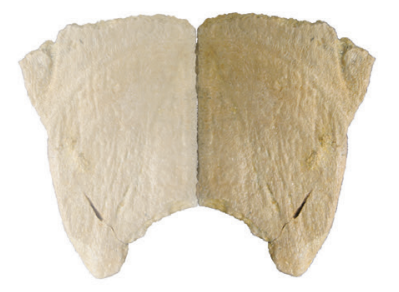

K

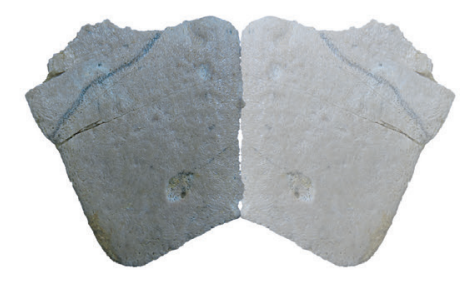

C

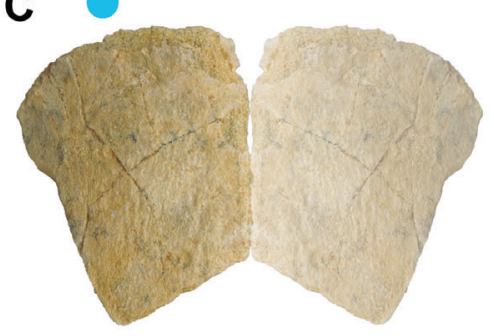

F

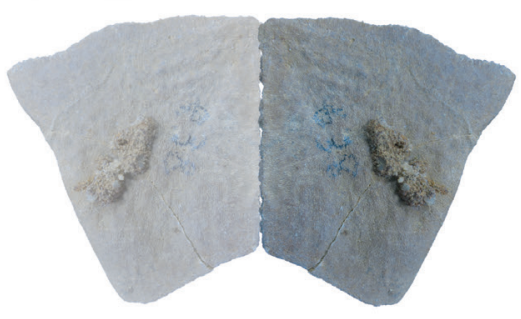

I

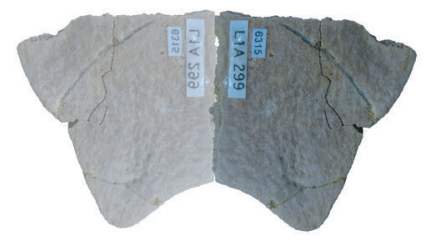

L

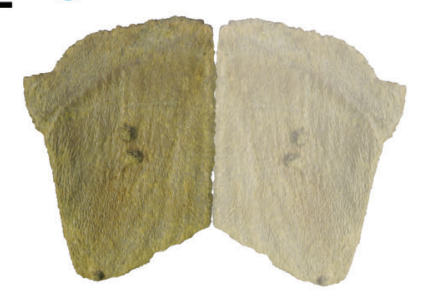

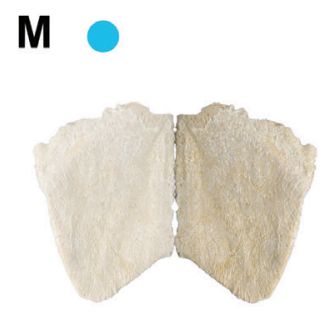
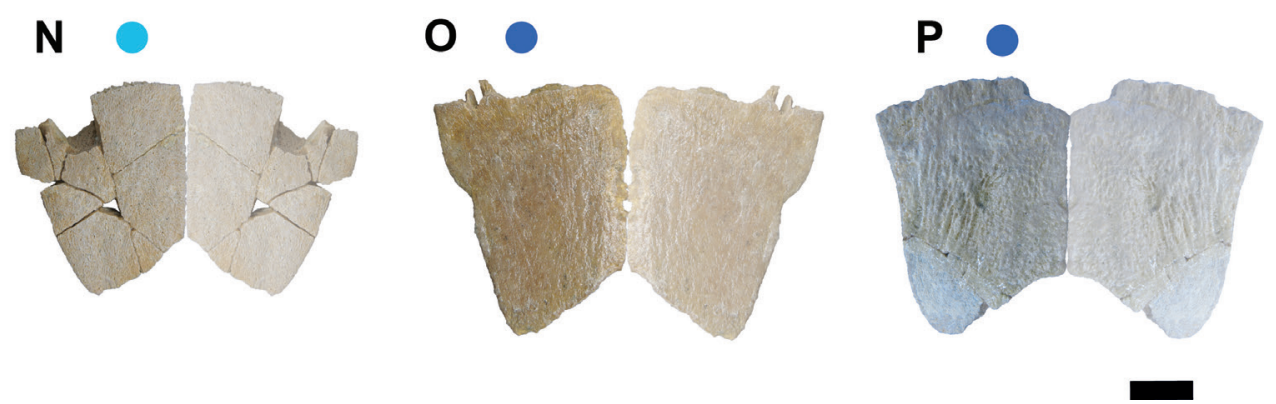

Figure 1. Xiphiplastra in ventral view of Dortoka vasconica (Pan-Pleurodira, Dortokidae), from the late Campanian-early Maastrichtian (Upper Cretaceous) site of Laño (Treviño County, Burgos, Spain). Each xiphiplastron has been united through the medial surface with the photograph of the same rotated, this latter with less contrast. Thus, the morphology of the complete posterior region of each of the plastral lobes is reconstructed. A, MCNA 16660 (left); B, MCNA 14334 (left); C, MCNA 16661 (right); D, MCNA 6851 (left); E, MCNA 6870 (right); F, MCNA 6881 (left); G, MCNA 16665 (right); H, MCNA 14333 (left); I, MCNA 6315 (left); J, MCNA 6705 (right); K, MCNA 6708 (right); L, MCNA 6847 (right); M, MCNA 16662 (left); N, MCNA 16663 (right); O, MCNA 16664 (right); P, MCNA 6909 (right). Circles correspond to the two morphotypes of xiphiplastron. Dark blue corresponds to the first morphotype, whereas light blue corresponds to the second one; scale bar $=1 \mathrm{~cm}$. 
plays in the morphological variations that distinguish the two morphotypes observed for the posterior lobe of Dortoka vasconica by Pérez-García et al. (2012). To correlate each morphotype with a specific sex, comparative-qualitative studies was performed with extinct species of different lineages of Pan-Pleurodira, including species from Southwestern Europe, but also from other continents (see Discussion). These comparisons were made through both the information available in the literature (Schleich, 1990; Jiménez-Fuentes, 2007; Cadena et al., 2013; Sullivan \& Joyce, 2017; Guerrero \& Pérez-García, 2019; Limaverde et al., 2020), and the direct observation of some taxa (see section S2 of the Supplementary Information for more details).

Likewise, several extant pleurodiran clades that are part of the current biodiversity have been included in order to increase the comparative framework and evaluate, in a preliminary way, how sexual dimorphism has been manifested throughout the evolutionary history of this lineage of turtles. The comparisons with these extant species were also carried out through the direct observation of some of them (see S3 of the Supplementary Information) and the information provided in previous studies (Pritchard, 1979; Bour, 1983; Ernst, 1986; Kuchling, 1988; Strydom, 2001; Iverson \& Vogt, 2002; Trembath \& Freier, 2004; García, 2005; Host, 2006; Gerlach, 2008; Broadley \& Boycott, 2009; Pritchard, 2008; Böhm, 2010; Ceballos-Fonseca, 2010; González-Zárate, 2014; Páez et al., 2012, 2013; Gallego-García \& Forero-Medina, 2014; Bour et al., 2016; Sepúlveda-Seguro et al., 2020).

A quantitative approach was performed for both $D$. vasconica and several extant forms. Extinct Pan-Pleurodiran compared through the qualitative framework were not included in the quantitative analyse due to the small sample size, as well as considering the poor preservation of some of them. Also, the criterion of only using extant forms was chosen because only in them it is indisputably known which sex corresponds each dimorph. Thus, as will be justified later (see Discussion), the interpretations made for some extinct forms are here recommended to be taken with caution.

Methods applied to the analysis of the variability of Dortoka vasconica. Two-dimensional geometric morphometric method (GMM) was performed to analyse the morphological variation present in the posterior plastral lobe of Dortoka vasconica. Specifically, this has been evaluated considering the region of the xiphiplastron that involves the anal notch, because the qualitative analyses of the extant pleurodiran taxa performed here show that the sexual dimorphism is not the main factor that produces the morphologic variation of the other regions of the xiphiplastra (e.g., the lateral margins).

Two-dimensional landmark protocol described by Zelditch et al. (2012) was adopted. Two landmarks and eight semilandmarks were employed for the anal notch region of $D$. vasconica (see S4 of the Supplementary
Information to the set of landmarks used). Scale bars were used to scale each digitized specimen. All of them were digitized using the tpsDig v.2.16 software (Rohlf, 2010a, 2010b, 2015). All the steps of the analyses were performed by the same operator to avoid interobserver variation in the data (Fruciano, 2016). All sets of landmarks were scaled, translated, and rotated, using Generalized Procrustes Analysis (GPA, Rohlf \& Slice, 1990; Zelditch et al., 2012). This procedure was performed in R v. 4.0.1 ( $R$ Core Team, 2020) through the function gpagen in geomorph (Adams et al., 2021). The semilandmarks were slid using bending energy (Gunz \& Mitteroecker, 2013), since it is the method that best fits with the nature of the study sample. In all cases, the analyses were performed with the shape data corrected for allometry (Mitteroecker et al., 2013). For the study of the shape variation, the main maximal axes were described using the Principal Component Analysis (PCA) obtained from the Procrustes residuals. The number of Principal Components (PC) to evaluate in each PCA were selected through the broken-stick method (Jackson, 1993). PCA was computed using the function gm.prcomp of the geomorph package.

Allometry was statistically tested through the logarithm to base 10 of centroid size [log (CS)] values (independent variable) of the specimens of each dataset against the Procrustes shape coordinates (dependent variable). The Regression was performed by the function proc $D$. Im of the geomorph R package. Likewise, a boxplot of the CS variation for each morphotype was performed to graphically visualise the distribution of each group. In addition, a $t$-test was performed to confirm that the means were significantly different. Both analyses were performed in R v. 4.0.1 ( $R$ Core Team, 2020). Multivariate normality was tested for the xiphiplastra. The Shapiro-Wilk test was also performed in R v. 4.0.1 (R Core Team, 2020), using the mvnormtest package v. 0.1-9 (Jarek, 2012).

Also, ANOVA (analysis of variance) was performed to assess the sexual dimorphism (i.e., sexual shape dimorphism as well as sexual size dimorphism) based on the morphotypes preliminary predefined in the literature (Pérez-García et al., 2012). This analysis was carried out using morphotypes as a factor with 10.000 permutations. A cross-validation test (i.e., leave-oneout cross-validation) was also performed to assess the accuracy of the classification between morphotypes.

Methods applied to the analysis of the variability of extant pleurodiran turtles. For the extant pleurodiran representatives, the same GMM protocol described above was followed. The anal notch morphology (for more details, see section S5 in the Supplementary Information) was analysed to allow the comparisons with the morphological variation identified for Dortoka vasconica.

As in the characterization of $D$. vasconica, all analyses were carried out with the shape data corrected for allometry and performed in R v. 4.0.1 (R Core 
Team, 2020). For each turtle clade, sexual shape dimorphism was also evaluated through a PCA obtained from the Procrustes residuals, using the function gm.prcomp of the geomorph package. The number of significant PC scores was estimated using the brokenstick method (Jackson, 1993). The species analysed in the quantitative approach were included based on the sample size of each of them as well as the preservation of the specimens. Only the species or genera in which sexual dimorphism has been previously documented were considered in our analyses.

The sexual size dimorphism in this study was analysed using box-plots of CS variation to see how this factor manifests in the extant forms. However, due to the small sample size of most members of Chelidae and Podocnemididae analysed through direct observations in this study, sexual size dimorphism was only evaluated for Pelomedusidae. In addition, a $t$-test was performed to determine if there was a significant difference between the means of both sexes.

\section{RESULTS}

Quantitative characterization of the sexual dimorphism in extant pleurodires

Sexual shape dimorphism. The PCA of morphogeometric data for the anal notch of the genus Podocnemis Wagler, 1830a is illustrated in the space defined by the first two components (Fig. 2A), which captures $82 \%$ of the total shape variance for the xiphiplastra. The shape variance kept by PC1 is associated with the relative width and depth of the anal notch, varying from wide and shallow (positive scores) to narrow and deep (negative scores). This character proves to be sexually dimorphic since, along the PC1 axis, both sexes of all Podocnemis species included in this study (i.e., Podocnemis expansa (Schweigger, 1812); Podocnemis lewyana Duméril, 1852; Podocnemis unifilis Troschel, 1848) are differentiated. In addition, the direction of the sexual selection acts in the same way in all these species. Thus, males have lower scores than females and vice versa. The PC2 eigenvalue principally concerns the relative width of the anterior margin. Positive scores are occupied by an anal notch with a wide anterior margin and vice versa for the negative scores. In this case, sexual morphotypes of Podocnemis lewyana are also distinguished along this axis. However, a greater sample size is necessary to confirm that such a difference between the sexes is really the result of sexual dimorphism instead of being the result of other types of intraindividual variability.

The first two principal components of the anal notch morphology of the chelids account for $79 \%$ of the total variance in the dataset (Fig. 2B). PC1 is associated with the curvature degree of the anal notch. Thus, positive scores are occupied by a relatively curved anal notch (i.e., U-shaped), whereas negative scores are described by a relatively straight one (i.e., V-shaped).
Figure 2B shows how not all the species considered here (e.g., Chelodina longicollis (Shaw, 1794) and Hydromedusa maximilliani (Mikan, 1825) maintain the same direction in the sexual selection of this character). Although most males tend to be in the most negative scores (i.e., U-shaped anal notch), the opposite occurs in one of these taxa (i.e., C. longicollis). Thus, the morphology of the anal notch of the females of this species is closer to that of the males of the other genera of Chelidae considered here (e.g., Mesoclemmys gibba (Schweigger, 1812)) rather than that of the females. The shape variance kept by PC2 mainly concerns the depth degree of the anal notch, being deeper as positive values increase and vice versa. In this case, it is also distinguished between both sexes in several of these taxa (e.g., C. longicollis, $H$. maximilliani and $M$. gibba), however, the direction of the sexual selection of these chelids is different. Thus, the females of $C$. longicollis and $H$. maximilliani are in the most positive scores, while the females of $M$. gibba are in the most negative scores.

The PCA of morphogeometric data for the anal notch of Pelomedusidae is illustrated in the space defined by the first two components (Fig. 2C), which captures $79 \%$ of the total shape variance for this plate. In this case, the PC1 eigenvalue also principally concerns the degree of curvature of the anal notch, being more curved (i.e., U-shaped) as positive scores increase, and vice versa. This axis distinguishes the sexes of the different taxa, while PC2 hardly separates sexual morphotypes. In this case, two different directions of sexual selection can be distinguished, which vary at the generical level. Specifically, the females of Pelomedusa Wagler, 1830b are in the most negative values, whereas females of the genus Pelusios Wagler, 1830b lie in the most positive ones. The shape variance kept by PC2 is associated with the degree of depth and the relative width of the anterior margin of the anal notch. Thus, positive values are described by a deep anal notch with a relatively wide anterior margin, and the opposite occurs for the negative scores. In this case, PC2 does not clearly separate both sexes.

Sexual size dimorphism. The box-plots of the CS variation for each sex are represented in Figure 3. The extant representatives of Pleurodira analysed quantitatively show the same trends in the direction of sexual size dimorphism as those observed in these same taxa via the qualitative approach (see Discussion). Specifically, as can be observed, it is evidenced that the direction of sexual size dimorphism can vary at the generical level. In this case, this is indicated via the comparison of the genera of Pelomedusidae. Thus, the sexual size dimorphism acts in favour of the female in Pelusios (Fig. 3A-E), whereas the trend is the opposite in Pelomedusa (Fig. 3F). $T$-test also revealed differences in the mean of the sexes between the two genera (see Fig. 3 for more details), which could be evidencing a difference 
A

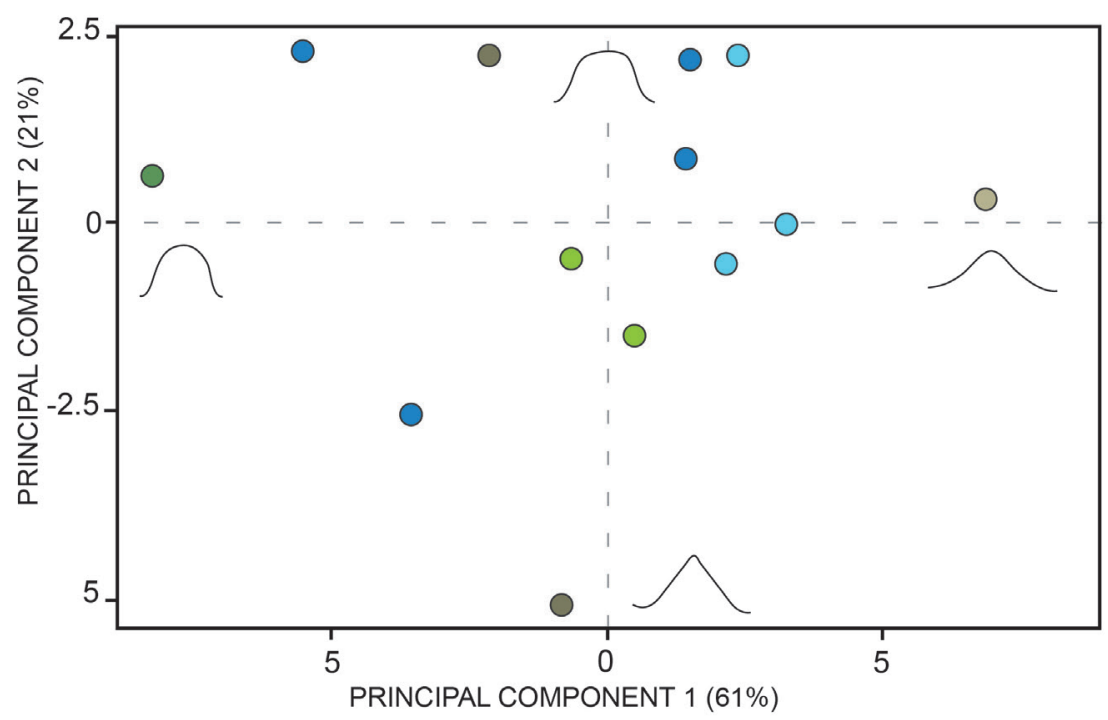

MALE

Podocnemis unifilis

Podocnemis expansa

- Podocnemis lewyana

FEMALE

Podocnemis unifilis

Podocnemis expansa

Podocnemis lewyana

B

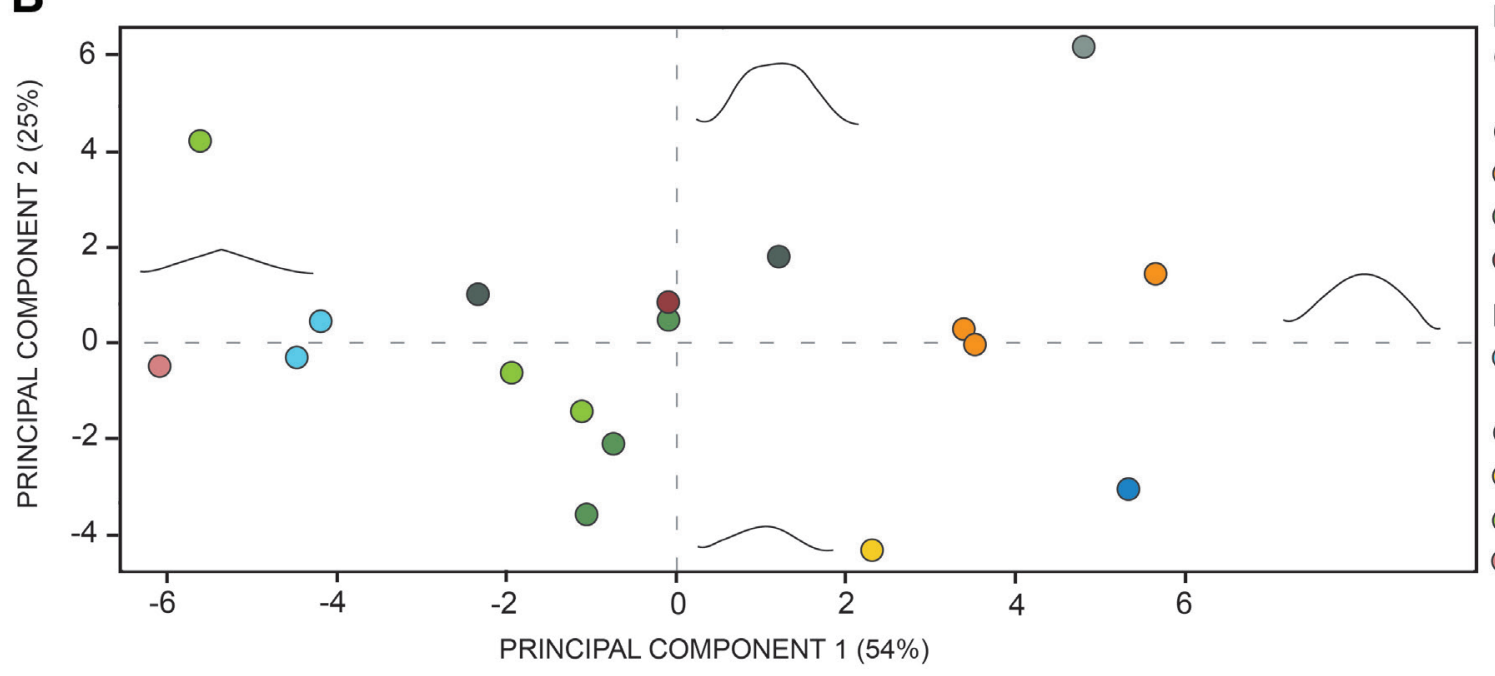

MALE

- Hydromedusa maximilliani

- Chelodina longicollis

- Mesoclemmys gibba

- Platemys platycephala

- Emydura kreffiti

FEMALE

Hydromedusa maximilliani

- Chelodina longicollis

- Mesoclemmys gibba

Platemys platycephala

Emydura kreffiti

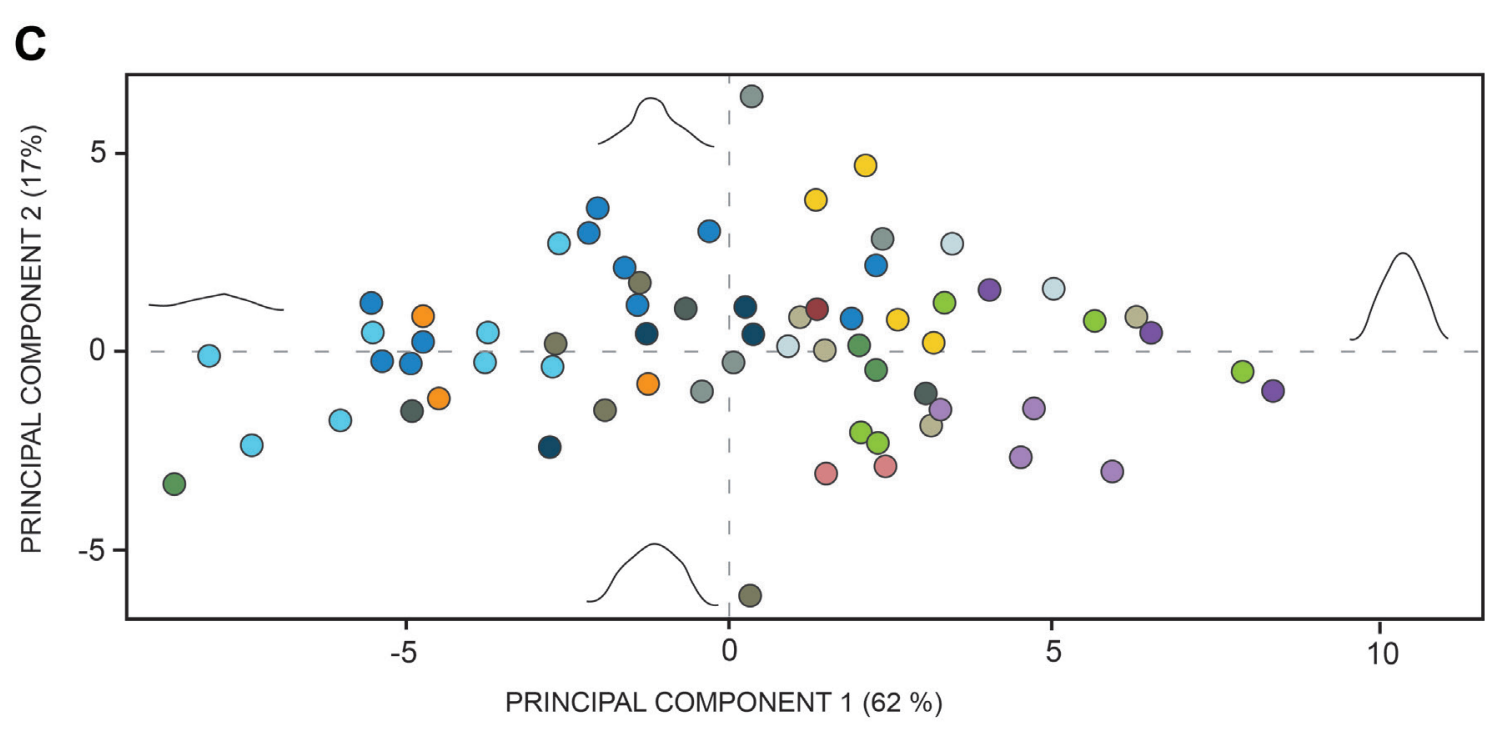

MALE

- Pelomedusa subrufa

- Pelusios castanoides

- Pelusios castaneus

Pelusios sinuatus

Pelusios adansoni

Pelusios chapini

- Pelusios gabonensis

- Pelusios subniger

FEMALE

- Pelomedusa subrufa

- Pelusios castanoides

- Pelusios castaneus

- Pelusios sinuatus

- Pelusios adansoni

- Pelusios chapini

- Pelusios gabonensis

- Pelusios subniger

Figure 2. Principal Component Analysis (PCA) performed on the xiphiplastron of extant pleurodiran representatives of the clades. A, Podocnemididae; B, Chelidae; C, Pelomedusidae. 
in the magnitude of the expression of the sexual size dimorphism. Thus, the means of both sexes are not significantly different in Pelusios ( $p>0.05$ ); on the contrary, Pelomedusa shows significant differences between the mean of both groups $(p<0.05)$. As can be observed in Figure 3, the statistical support of the majority of taxa is relatively low, therefore, these results should have to been carefully taken.

A

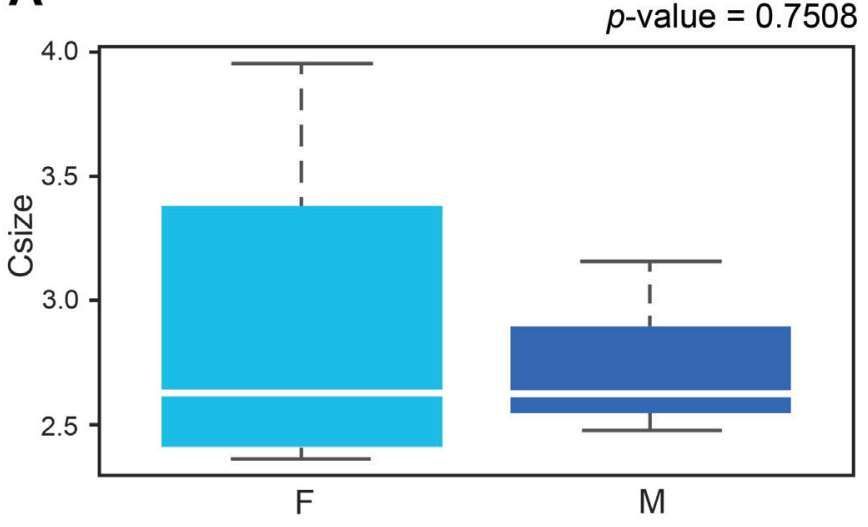

C

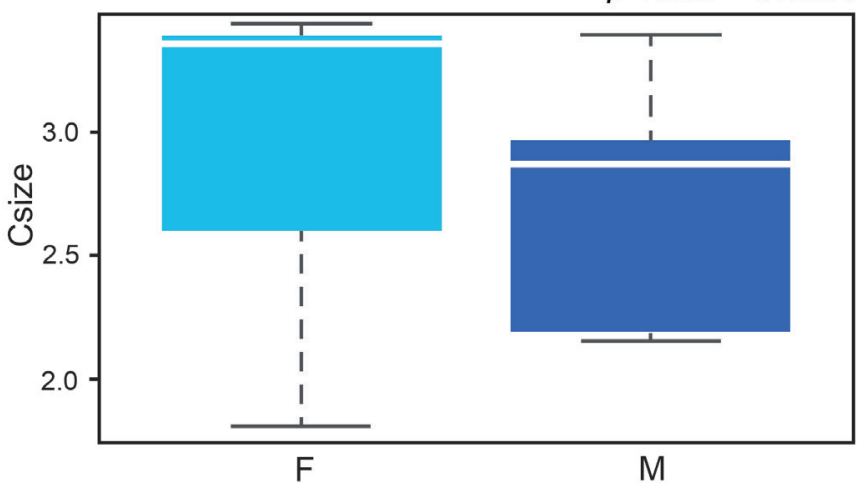

$p$-value $=0.5606$

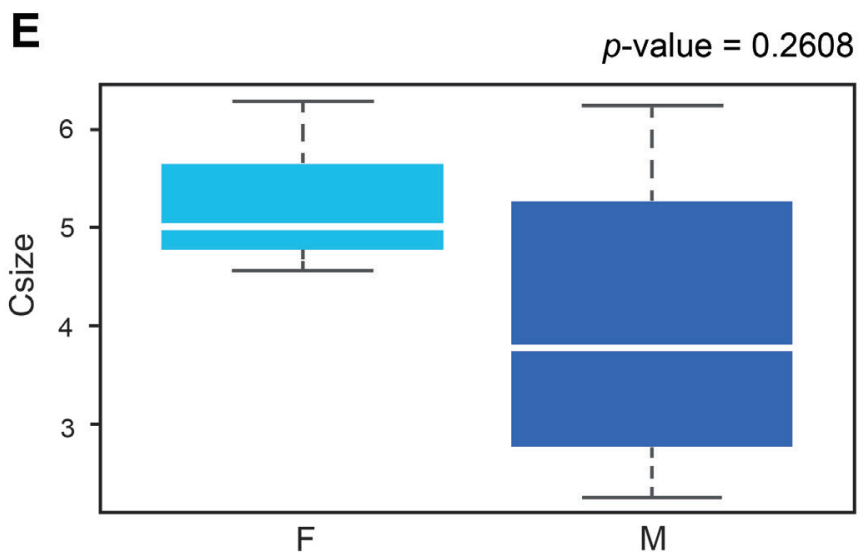

Quantitative characterization of the sexual dimorphism in Dortoka vasconica

Sexual shape dimorphism. Shapiro-Wilk tests indicated a normal distribution $(p>0.05)$ for xiphiplastra. The PCA of the morphogeometric data for the anal notch in Dortoka vasconica is illustrated in the space defined by the first three components (Fig. 4A-B), which

B

$p$-value $=0.6594$

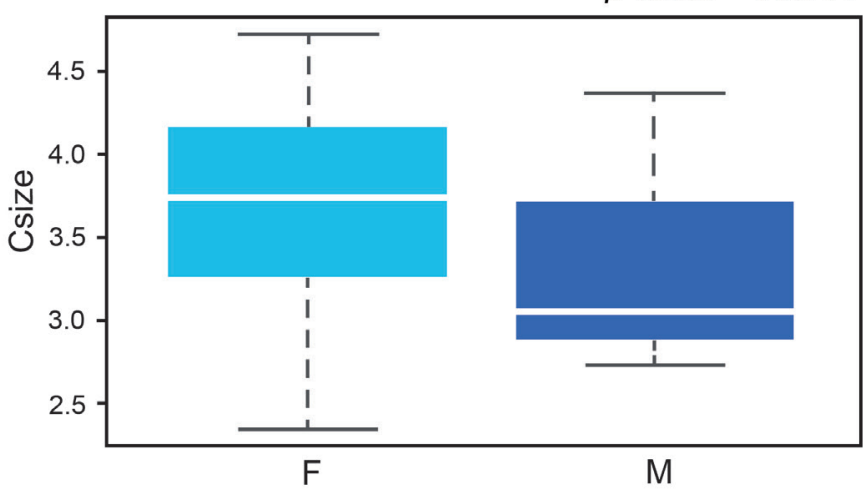

D $p$-value $=0.7162$

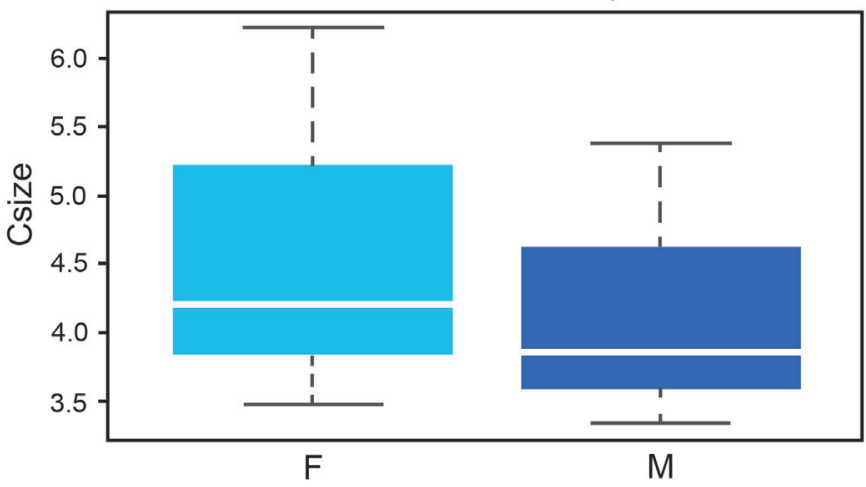

F $p$-value $=0.0326$

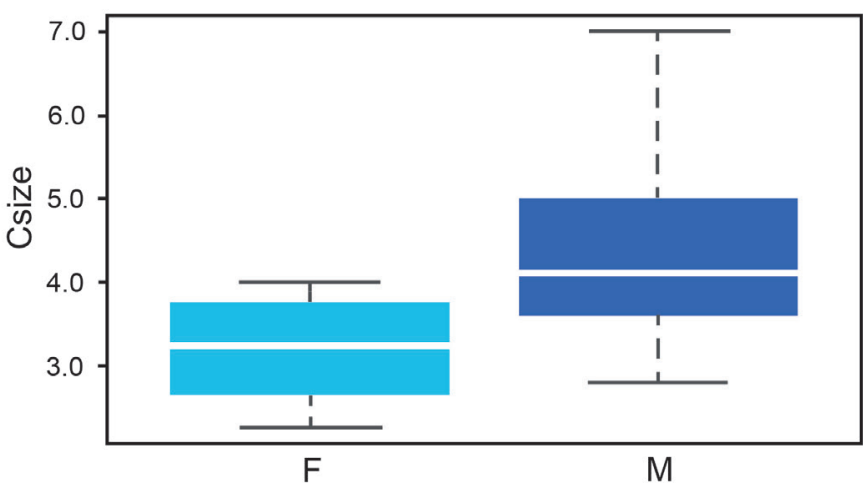

Figure 3. Box-plots of the centroid size (CS) of the xiphiplastron of extant representatives of the clade of Pleurodira Pelomedusidae. A, Pelusios adansonii; B, Pelusios castaneus; C, Pelusios castanoides; D, Pelusios gabonensis; E, Pelusios subniger, F, Pelomedusa subrufa. 
captures $81 \%$ of the total shape variance for this region. The PC1 eigenvalue principally concerns the depth and morphology of the anal notch, varying from shallow V-shaped (negative scores; e.g., MCNA 6708, Fig. 1K) to deep U-shaped (positive scores; e.g., MCNA 14333, Fig. $1 \mathrm{H}$ ). In this axis, positive scores corresponding to specimens of the first morphotype and negative to the second one. The shape variance kept by PC2 is associated with the width of the anterior margin of the anal notch. As positive scores increase, the anterior margin of the anal notch is wider (e.g., MCNA 14333, Fig. $1 \mathrm{H}$ ) and vice versa (e.g., MCNA 16664, Fig. 10). PC3 principally concerns the degree of concavity and the relative width of the anal region. Positive scores are occupied by a curved and relatively wide anal notch (e.g., MCNA 6870, Fig. 1E), whereas those in the negative scores are straight and relatively narrow (e.g., MCNA 16660, Fig. 1A). As can be observed in (Fig. $4 A-B)$, none of the principal components itself achieve a good separation of preestablished morphotypes. However, these morphotypes are clearly differentiated when considering PC1 and PC3 together.

Procrustes ANOVA (Tab. 1) reveals significant differences in the morphology of the anal notch between morphotypes ( $p$-value < 0.05). The cross-validation test shows a high percentage of correctly classified morphotypes (72.5\%).

Sexual size dimorphism. The regression indicates that the xiphiplastron of Dortoka vasconica is influenced

A

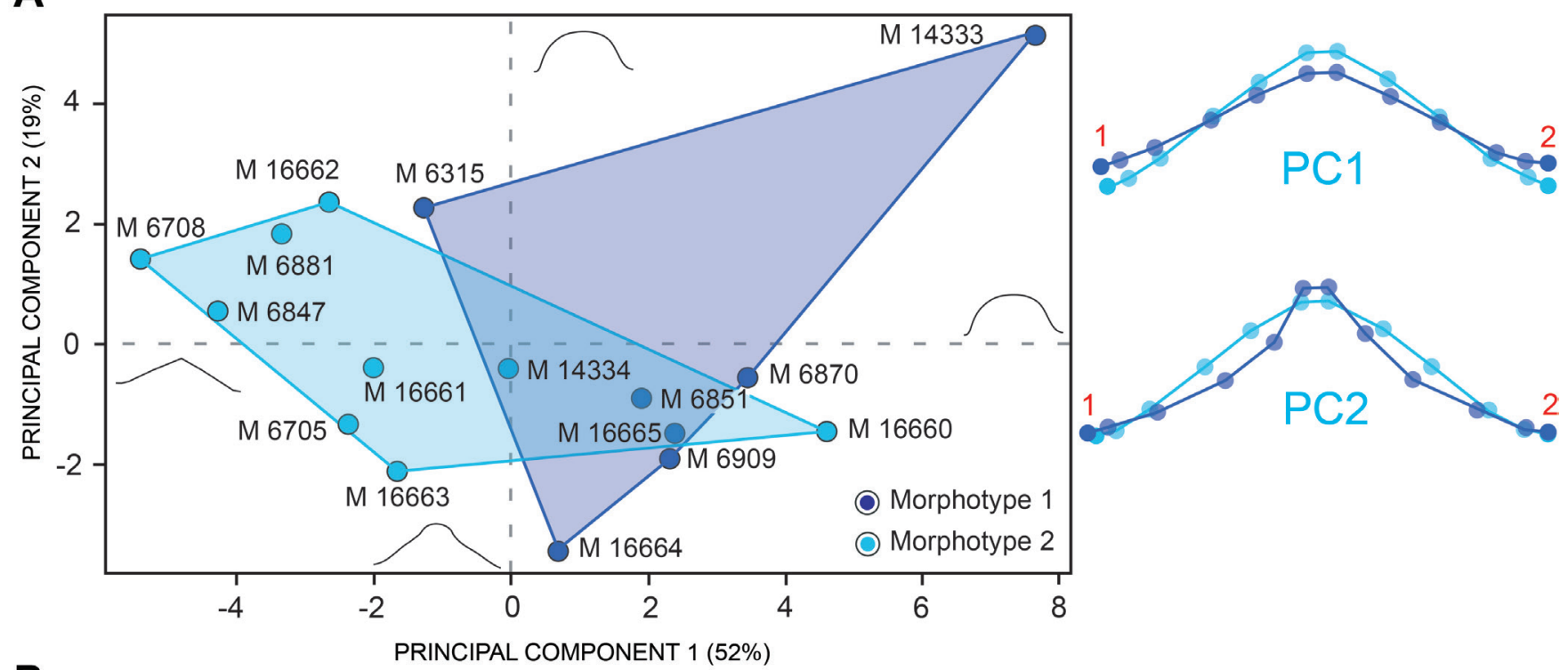

B

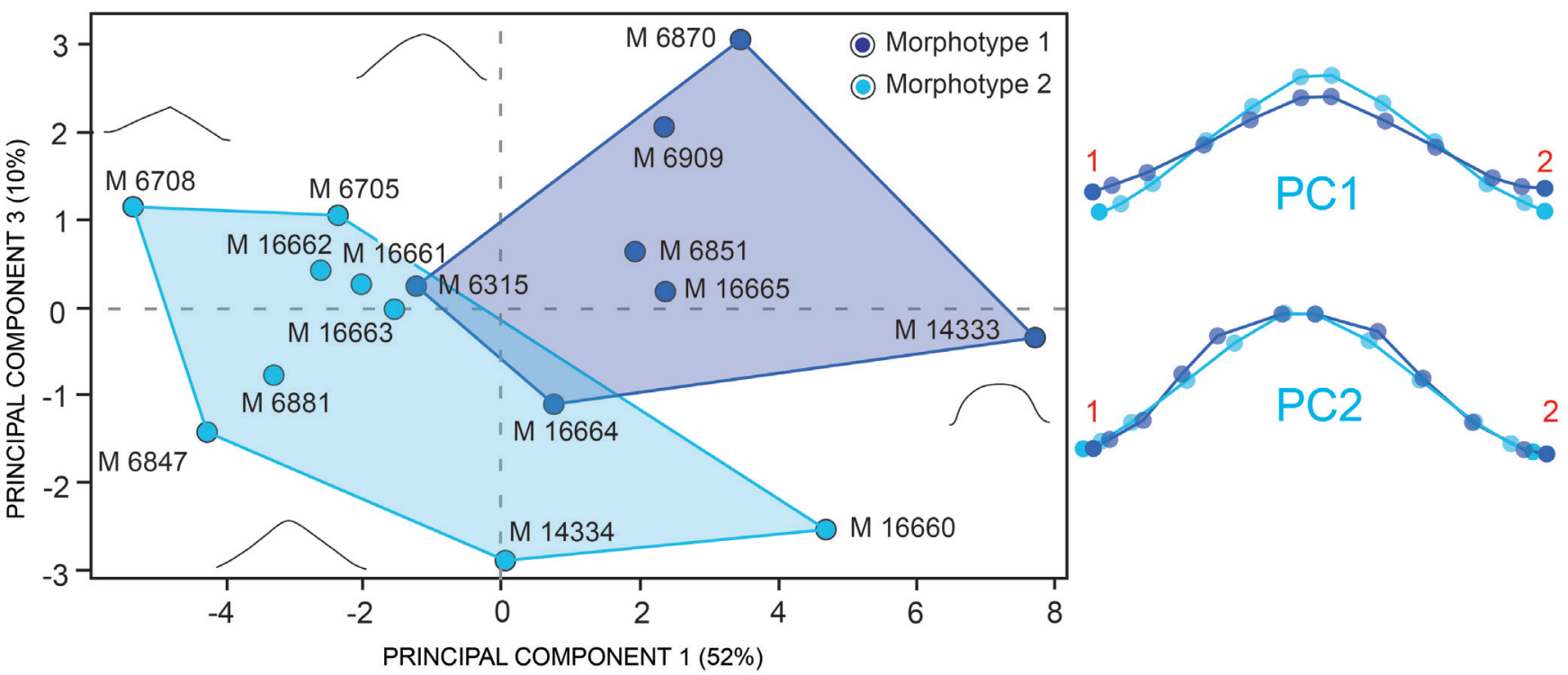

Figure 4. Shape differences of the xiphiplastron of Dortoka vasconica (Pan-Pleurodira, Dortokidae), from the late Campanianearly Maastrichtian (Upper Cretaceous) site of Laño (Treviño County, Burgos, Spain). A-B, Principal Component Analysis (PCA). Wireframes indicate the main shape changes of each PC, the light blue concerns the average shape, whereas the dark blue is the shape variance related to extremes of variation along the axis. 
Table 1. Results of the Procrustes ANOVA testing for shape and size differences between the two morphotypes of xiphiplastron. Abbreviations: SS, Procrustes sums of squares; MS, Procrustes mean squares; Rsq, R-squared; df, degrees of freedom; F, Goodall's F statistic; $\mathbf{P}$, parametric $p$-value.

\begin{tabular}{l|c|c|c|c|c|c} 
& SS & MS & Rsq & df & F & P \\
\hline Log (Csize) & 0.015740 & 0.0157404 & 0.19373 & 1 & 4.0171 & 0.023 \\
Morphotype & 0.014571 & 0.0145706 & 0.17933 & 1 & 3.7186 & 0.024 \\
Residual & 0.050938 & 0.0039183 & 0.62694 & 13 & & \\
Total & 0.081249 & & & 15 & & \\
\hline
\end{tabular}

by allometry $(p<0.05)$, where $20.81 \%$ of the shape variation can be explained by differences in size among specimens (for more details see Fig. 5A). Likewise, this is also evidenced by Procrustes ANOVA $(p<0.05$; for more details, see Tab. 1). The box-plot graphically shows the differences in distribution between both xiphiplastral morphotypes, being relatively separated with a low overlap (Fig. 5B). T-test revealed no accentuated differences between the mean of both groups $(p>0.05)$.

\section{DISCUSSION}

Sexual Shape Dimorphism in extinct and extant pan-pleurodires

Turtles exhibit a wide assemblage of sexually dimorphic characters that can manifest through sexual shape dimorphism (Kuchling, 1997; Pritchard, 2008; Bonnet et al., 2010) or sexual size dimorphism (the most studied form of dimorphism between the sexes; Leuteritz \& Gantz, 2013; Regis \& Meik, 2017). For the extinct forms, only a few of these sexually dimorphic characters are available (Bonnet et al., 2010; Cadena et al., 2013; Limaverde et al., 2020; Szczygielski et al., 2018), which considerably complicates the evaluation of their sexual dimorphism.

In this study, the quantitative approach demonstrated an evident sexual shape dimorphism in the morphology of the anal notch of Dortoka vasconica, the two sexual morphotypes previously observed by Pérez-García et al. (2012) being characterized. Likewise, both dimorphs coincide with those observed in extant and extinct panpleurodiran turtles. Specifically, in the formers, the variation of the xiphiplastral area is identified in a great number of taxa as sexually dimorphic (Host, 2006; Pritchard, 2008; Ceballos-Fonseca, 2010). However, in the literature, the direction as well as the magnitude of the sexual dimorphism have been recognized as variable at genus level in extant pleurodiran turtles, without following a clear phylogenetic pattern. Thus, the anal notch of representatives of different clades but also of different genera of the same clade, belonging to the same sex, can be V-shaped (e.g., females of the genus of Podocnemididae Podocnemis; GonzálezZárate, 2014; Páez et al., 2013; Gallego-García \& Forero-Medina, 2014; Sepúlveda-Seguro et al., 2020) or U-shaped (e.g., females of the genus of Chelidae Chelodina Fitzinger, 1826 and of that of Pelomedusidae Pelusios, Host, 2006; Gerlach, 2008). In addition, sexual dimorphism can be significant in some genera (e.g., in the podocnemidids Podocnemis, Páez et al., 2012, 2013) but, by contrast, not in other representatives of the same clade, showing similar morphologies between both sexes (e.g., in the Podocnemidid Erymnochelys Baur, 1888; Kuchling, 1988; García, 2005).

In regard to the extinct pan-pleurodiran turtles, the xiphiplastral morphology it has been commonly used as the main character to establish the sexes. Thus, two morphotypes considering this plastral area have
A

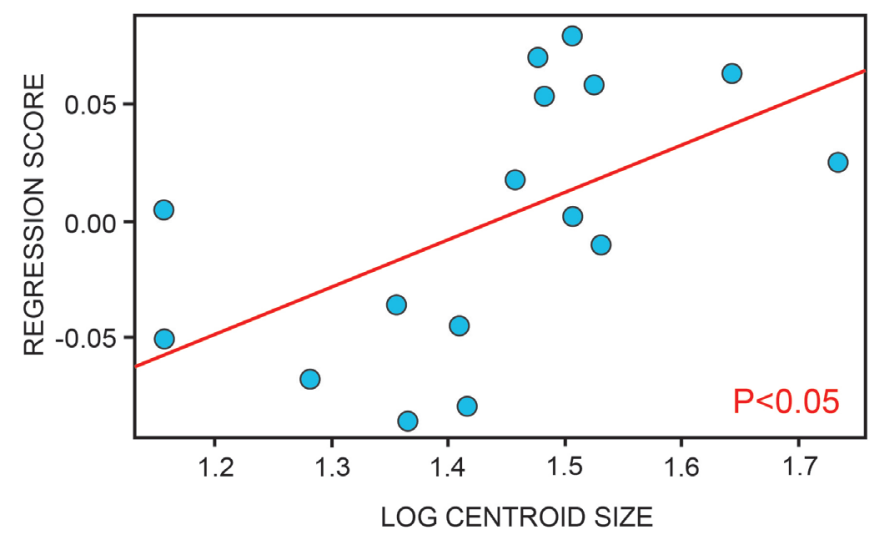

B

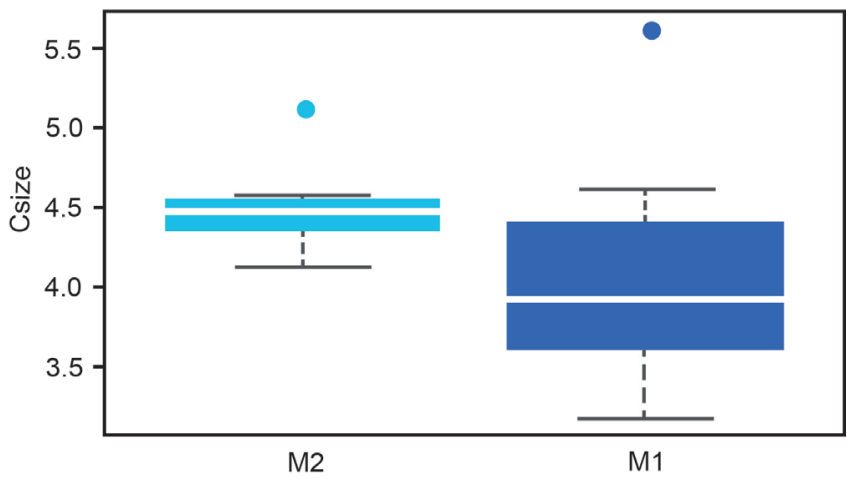

Figure 5. Size differences of the xiphiplastron of Dortoka vasconica (Pan-Pleurodira, Dortokidae), from the late Campanianearly Maastrichtian (Upper Cretaceous) site of Laño (Treviño County, Burgos, Spain). A, Linear Regression between Procrustes coordinates (dependent variable) and logged-centroid size values (independent variable); B, Box-plot of centroid size (CS). 
been documented for both representatives of the stem group of Pleurodira (i.e., members of the clade of basal pan-pleurodires Platychelyidae, Cadena et al., 2013; Sullivan \& Joyce, 2017), as well as for extinct representatives of the main lineages of the crown group (i.e., Pelomedusidae, Schleich, 1990; Limaverde et al., 2020; Bothremydidae, Guerrero \& Pérez-García, 2019; and Podocnemididae, Jiménez-Fuentes, 2007). In general, in the study of extinct turtles, the same direction of sexual selection has been considered in all these studies in which individuals have been sexed. Thus, the specimens with long and narrow posterior xiphiplastral processes and a well-developed anal notch showing a U-shape were identified as males, and the specimens with short and wide processes and a V-shaped anal notch were recognized as females. This criterion has been used for the representatives of the extinct basal group Platychelyidae (for the species Notoemys zapatocaensis Cadena-Rueda \& Gaffney, 2005 and Platychelys oberndorferi Wagner, 1853; Cadena et al., 2013; Sullivan \& Joyce, 2017), as well as for extinct representatives of Araripemydidae (e.g., the species Araripemys barretoi Price, 1973; Schleich, 1990; Limaverde et al., 2020) and Podocnemididae (e.g., the species Neochelys aff. salmanticensis (Jiménez-Fuentes, 1968, 2007). In no species of Bothremydidae in which the sexual dimorphism has been recognized the sex of each of the morphotypes has been specified (e.g., Algorachelus peregrina Pérez-García, 2016; Guerrero \& Pérez-García, 2019). Thus, as qualitatively and quantitatively (see Results) demonstrated for some pleurodiran clades that are part of the current biodiversity, the magnitude and direction of sexual selection for this trait vary at the genus level. Therefore, although the sex for the basal pan-pleurodires had been interpreted, by previous authors, on the basis of the morphology of the anal notch (e.g., Notoemys zapatocaensis and Platychelys oberndorferi; Cadena et al., 2013; Sullivan \& Joyce, 2017), we demonstrated here that this approach (i.e., the general attribution of the U-shaped for males and $\mathrm{V}$-shaped as females) has to be taken with caution. However, it is evidenced the sexual dimorphism was already well-developed in the anal notch of the basal pan-pleurodires (Dortokidae and Platychelyidae).

\section{Sexual size dimorphism in extinct and extant Pan-} pleurodires

Most extant pleurodiran turtles show at least some degree of sexual size dimorphism. As with the sexual shape dimorphism, the magnitude and direction of this trait varies, at least, at the generical level (e.g., being opposite in the chelids Platemys Wagler, 1830b and Emydura Bonaparte, 1836; Ernst, 1986; Trembath \& Freier, 2004; Böhm, 2010; the pelomedusids Pelomedusa and Pelusios; Pritchard, 1979; Bour, 1983; Strydom, 2001; Broadley \& Boycott, 2009; Bour et al., 2016; and the podocnemidids Peltocephalus Duméril \&
Bibron, 1835 and Podocnemis; Iverson \& Vogt, 2002; Páez et al., 2012, 2013; Gallego-García \& ForeroMedina, 2014), without a single phylogenetic pattern for each of the clades. In Dortoka vasconica, only size differences between morphotypes were observed in the xiphiplastral region, which could indicate sexual size dimorphism. However, this result cannot be confirmed, since it cannot be determined with total certainty that these size variations are not the result of other types of intraspecific variation (e.g., ontogeny). It must be considered that turtles have an indeterminate growth, which is problematic when studying extinct species due to possible confusing interactions between age and size distributions. Likewise, it is common in turtles for a sex to become sexually mature at a younger age (Gibbons \& Lovich, 1990; Halámková et al., 2013). Therefore, it is very difficult to guarantee that young individuals of the larger sex are not mixed with older individuals of the smaller sex. In this context, despite having considered all known xiphiplastra of $D$. vasconica (i.e., both all previously published material and all available unpublished specimens), a greater sample size would be required to address these points.

It has been commonly reported in the literature that the direction and magnitude of the sexual size dimorphism can be the result of the interaction of several factors (i.e., the mating system, habitat type, latitude, phylogeny, and ecology; Berry \& Shine, 1980; Bonnet et al., 2010; Agha et al., 2018). Therefore, the simultaneous action of these factors in these two parameters makes it very complex to determine the sexual dimorphism in this sexual trait. In this study, this same degree of complexity was reflected in the characterization of the sexual selection of sexual size dimorphism for Pleurodira. In this case, it was observed how the direction of sexual size dimorphism varies at the generical level in all the clades living today (e.g., Platemys and Emydura in Chelidae; Podocnemis and Peltocephalus in Podocnemididae; and Pelomedusa and Pelusios in Pelomedusidae; Pritchard, 1979; Ernst, 1986; Iverson \& Vogt, 2002; Páez et al., 2012, 2013), without following any specific pattern. This trend was also evidenced, in a very preliminary way, in the statistical analyses performed here. Consequently, this ambiguity in the direction of sexual size dimorphism demonstrates, once again, the degree of complexity in determining sexual size dimorphism for extinct taxa. Therefore, in this sense, the use of sexual size dimorphism as a sex predictor by itself is not supported for $D$. vasconica or any other extinct pan-pleurodiran taxa.

It is important to underline that most analyses of both sexual shape dimorphism and sexual size dimorphism were performed over a limited sample. Therefore, a greater sample size would be recommended to obtain more consistent statistical results. However, despite this limitation, the conclusions do not vary since the same general results in the extant pleurodiran turtles have also evidenced through qualitative analysis. 


\section{CONCLUSIONS}

Dortoka vasconica, the type species of the freshwater turtle clade Dortokidae, is one of the best-represented basal forms of Pan-Pleurodira worldwide. After the original description of $D$. vasconica, the posterior study performed on the abundant remains from its type locality (Laño, Treviño County, Burgos; late Campanian-early Maastrichtian), significantly improved the knowledge regarding its anatomy and palaeoecology. Thus, this previous study on its variability allowed to recognize, preliminary, two morphotypes based on the posterior plastral area, possibly linked to sexual dimorphism. Also, two morphotypes were identified considering the morphology of the anterior plastral lobe and those of its plates and scutes. However, a correlation with the previously indicated morphotypes could not be established due to the disarticulation of all specimens and the limited studies carried out, both in extant and extinct pan-pleurodiran taxa, about the sexual dimorphism. Therefore, this lack of information has not allowed, until now, the analysis of sexual variation in basal forms such as Dortoka vasconica.

In this context, the detailed study of the morphological variation of the putative sexual traits of Dortoka vasconica allows us to recognize, through a quantitative approach, a significant sexual dimorphism in the anal notch. The integration of comparative material belonging to the most significant groups of extinct and extant pan-pleurodiran turtles evidenced, through a qualitative and quantitative framework, a similar sexual variation to that recognized in Dortoka vasconica. In addition, the review of the sexual dimorphism in extant representatives of Pleurodira did not evidence a clear pattern in the magnitude and direction of both the sexual shape dimorphism, and the sexual size dimorphism. Therefore, due to the lack of recognition of a clear phylogenetic trend for both factors, the sexing of extinct pan-pleurodiran taxa is questioned here, especially considering the more basal representatives.

Supplementary Information. Supplementary material of this manuscript is available at the Spanish Journal of Palaeontology web-site (https://sepaleontologia.es/spanish-journalpalaeontology/) linked to the corresponding contribution. The information provided by the author has not being copy edited or substantially formatted.

Author contributions. A.G and A.P.-G. analyzed the data, A.G wrote the paper and prepared the figures, A.P.-G. reviewed the drafts and final version of the paper. All authors approved the final version of the manuscript and agree to be held accountable for the content therein.

Competing Interest. We declare we have no competing interests.

Funding. This work was funded by the Spanish Society of Palaeontology through the help research grant 2019 (AJISEP-2019).

Author details. Andrea Guerrero \& Adán Pérez-García. Grupo de Biología Evolutiva, Facultad de Ciencias, UNED, Paseo Senda del Rey 9, 28040 Madrid, Spain. guerbach@ gmail.com, paleontologo@gmail.com
Acknowledgments. We acknowledge Carmelo Corral (MCNA), Salvador Bailón (MNHN.ZA.AC), Roger Bour and Laure Pierre (MNHN.RA) for access to material of extinct and extant pan-pleurodiran taxa. The authors also thank the editorial work done by Sonia Ros-Franch and Carlos Martínez-Pérez (University of Valencia, Spain) and Humberto G. Ferrón (University of Bristol, UK), as well as X. Murelaga (University of the Basque Country, Spain) and an anonymous reviewer for their useful comments and their constructive reviews.

\section{REFERENCES}

Adams, D. C., Collyer, M. L., Kaliontzopoulou, A., \& Balken, E. (2021). Geomorph: Software for geometric morphometric analyses. $\mathrm{R}$ package version 3.3.2.

Agha, M., Ennen, J. R., Nowakowski, A. J., Lovich, J. E., Sweat, S. C., \& Todd, B. D. (2018). Macroecological patterns of sexual size dimorphism in turtles of the world. Journal of Evolutionary Biology, 31(3), 336-345. doi: 10.1111/jeb.13223

Baur, G. (1888). Osteologische Notizen über Reptilien. Fortsetzung III. Zoologischer Anzeiger, 11(285), 417424.

Berry, J. F., \& Shine, R. (1980). Sexual size dimorphism and sexual selection in turtles (order Testudines). Oecologia, 44(2), 185-191. doi: 10.1007/BF00572678

Böhm, S. (2010). Ecology of chelid turtles Platemys platycephala, Mesoclemmys gibba and Mesoclemmys nasuta in French Guyana. With notes on short term migrations and dietary spectrum of Platemys platycephala in the Nouragues Field Reserve, French Guyana. (PhD Thesis, Universität Wien, Viena).

Bonaparte, C. L. (1836). Cheloniorum Tabula Analytica. Rome.

Bonnet, X., Delmas, V., El-Mouden, H., Slimani, T., Sterijovski, B., \& Kuchling, G. (2010). Is sexual body shape dimorphism consistent in aquatic and terrestrial chelonians? Zoology, 113(4), 213-220.

Bour, R. (1983). Trois populations endémiques du genre Pelusios (Reptilia, Chelonii, Pelomedusidae) aux îles Seychelles; relations avec les espèces africaines et malgaches. Bulletin du Muséum national d'histoire naturelle, 5(1), 343-381.

Bour, R., Luiselli, L., Petrozzi, F., Hoinsoudé Segniagbeto, G., \& Chirio, L. (2016). Pelusios castaneus (Schweigger 1812) - West African Mud Turtle, Swamp Terrapin. Chelonian Research Monographs, 5, 095.1-095.11. doi: 10.3854/crm.5.095.castaneus.v1.2016

Broadley, D. G., \& Boycott, R. C. (2009). Pelusios sinuatus (Smith1838) - Serrated Hinged Terrapin. Chelonian Research Monographs, 5, 036.1-036.5. doi: 10.3854/ crm.5.036.sinuatus.v1.2009

Cadena-Rueda, E. A., \& Gaffney, E. S. (2005). Notoemys zapatocaensis, a New Side-Necked Turtle (Pleurodira: Platychelyidae) from the Early Cretaceous of Colombia. American Museum Novitates, 3470, 1-19. doi: 10.1206/0003082(2005)470<0001:nzanst>2.0.co;2

Cadena, E. A., Jaramillo, C. A., \& Bloch, J. I. (2013). New material of the platychelyid turtle Notoemys zapatocaensis from the Early Cretaceous of Colombia; implications for understanding Pleurodira evolution". In D. B. Brinkman, P. A. Holroyd, \& J. D. Gardner (Eds.), Morphology and evolution of turtles (pp. 105-120). Springer. doi: 10.1007/978-94-007-4309-0_8 
Cadena, E., \& Joyce, W. G. (2015). A Review of the Fossil Record of Turtles of the Clades Platychelyidae and Dortokidae. Bulletin of the Peabody Museum of Natural History, 56(1), 3-20. doi: 10.3374/014.056.0101

Ceballos-Fonseca, C. P. (2010). Phenotypic plasticity, sexual dimorphism and Rensch's rule in turtles. (PhD Thesis, lowa State University, Ames, lowa). doi: 10.31274/etd180810-2011

Duméril, A. H. A. (1852). Description des reptiles nouveaux ou imparfaitement connus de la collection du Muséum d'Histoire Naturelle et remarques sur la classification et les caractères des reptiles. Premiere Mémoire. Ordre des chéloniens et premières familles de l'ordre des sauriens (crocodiliens et caméléoniens). Archives du Muséum d'Histoire Naturelle.

Duméril, A. M. C., \& Bibron, G. (1835). Erpétologie Générale ou Histoire Naturelle Complète des Reptiles. Tome second. Librairie Encyclopédique de Roret.

Ernst, C. H. (1986). Platemys, Platemys platycephala. Catalogue of American Amphibians and Reptiles, 405 $1-4$.

Fitzinger, L. J. (1826). Neue Classification der Reptilien, nach ihren Natürlichen Verwandtschaften nebst einer Verwandtschafts-Tafel und einem Verzeichnisse der Reptilien-Sammlung des k.k. Zoologischen Museum zu Wien.

Fruciano, C. (2016). Measurement error in geometric morphometrics. Development Genes and Evolution, 226(3), 139-158.

Gallego-García, N., \& Forero-Medina, G. (2014). Plan de manejo para la tortuga de río Podocnemis lewyana en la cuenca del río Sinú. Corporación Autónoma Regional de los Valles del Sinú y del San Jorge, Empresa Urrá S.A. E.S.P., Wildlife Conservation Society, Turtle Survival Alliance y Conservación Internacional. Montería, Colombia.

García, G. (2005). Ecology, human impact and conservation for the Madagascan side-necked turtle (Erymnochelys madagascariensis Grandidier, 1867) at Ankarafantsika National Park, Madagascar. (PhD Thesis. University of University of Kent, Canterbury, Great Britain).

Gerlach, J. (2008). Pelusios castanoides intergularis Bour 1983 - Seychelles Yellow-Bellied Mud Turtle, Seychelles Chestnut-Bellied Terrapin. Chelonian Research Monographs, 5, 010.2-010.4. doi: 10.3854/crm.5.010.intergularis.v1.2008

Gheerbrant, E., Codrea, V., Hosu, A., Sen, S., Guernet, C., De Lapparent, F., \& Riveline, J. (1999). Découverte en Transylvanie (Roumanie) de gisements à vertébrés dans les calcaires de Rona (Thanétien ou Sparnacien): les plus anciens mammifères cénozoïques d'Europe Orientale. Eclogae Geologicae Helvetiae, 92, 517-535.

Gibbons, J. W., \& Lovich, J. E. (1990). Sexual dimorphism in turtles with emphasis on the slider turtle (Trachemys scripta). Herpetological monographs, 4, 1-29. doi: 10.2307/1466966

González-Zárate, A., Montenegro, O., Castaño-Mora, O. V., \& Vargas-Ramírez, M. (2014). Abundancia, estructura poblacional y conservación de Podocnemis lewyana (Podocnemididae) en el río Prado, Colombia. Acta Biológica Colombiana, 19(3), 351-361. doi: 10.15446/ abc.v19n3.41565

Guerrero, A., \& Pérez-García, A. (2019). Análisis preliminar de la variabilidad intraespecífica en los xifiplastrones de la tortuga Algorachelus peregrina mediante morfometría geométrica. Zubía, 31, 133-138.

Gunz, P., \& Mitteroecker, P. (2013). Semilandmarks: a method for quantifying curves and surfaces. Hystrix, the Italian Journal of Mammalogy, 24(1), 103-109. doi: 10.4404/ hystrix-24.1-6292

Halámková, L., Schulte, J. A., \& Langen, T. A. (2013). Patterns of sexual size dimorphism in Chelonia. Biological Journal of the Linnean Society, 108(2), 396-413. doi: 10.1111/j.1095-8312.2012.02015.x

Host, B. M. (2006). Husbandry Manual for Eastern Snake Necked Turtle, Chelodina Iongicollis, Reptilia: Chelidae. Western Sydney Institute of TAFE, Richmond.

Iverson, J. B., \& Vogt, R. C. (2002). Peltocephalus, P. dumerilianus. Catalogue of American Amphibians and Reptiles, 744, 1-4.

Jackson, D. A. (1993). Stopping rules in principal components analysis: a comparison of heuristical and statistical approaches. Ecology, 74(8), 2204-2214. doi: $10.2307 / 1939574$

Jarek, S. (2012). mvnormtest: Normality test for multivariate variables. $\mathrm{R}$ package version 0.1-9.

Jiménez-Fuentes, E. (1968). Stereogenys salmanticensis, nov. sp., quelonio eocénico del Valle del Duero. Estudios Geológicos, 24(3-4), 191-203.

Jiménez-Fuentes, E. (2007). Los Pelomedusidae (Chelonia) del Eoceno de Corrales del Vino (Zamora, España). Studia Geologica Salmanticensia, 43(2), 227-245.

Kuchling, G. (1988). Population structure, reproductive potential and increasing exploitation of the freshwater turtle Erymnochelys madagascariensis. Biological Conservation, 43(2), 107-113. doi: 10.1016/0006-3207(88)90085-7

Kuchling, G. (1997). The Reproductive Biology of the Chelonia. Springer.

Lapparent de Broin, F., \& Murelaga, X. (1996). Une nouvelle faune de chéloniens dans le Crétacé supérieur européen. Comptes Rendus de l'Académie des Sciences, 323(Série Ila), 729-735.

Lapparent de Broin, F., \& Murelaga, X. (1999). Turtles from the Upper Cretaceous of Laño (Iberian Peninsula). Estudios del Museo de Ciencias Naturales de Álava, 14(1), 135-211.

Lapparent de Broin, F., Murelaga, X., \& Codrea, V. (2004). Presence of Dortokidae (Chelonii, Pleurodira) in the earliest Tertiary of the Jibou Formation, Romania: paleobiogeographical implications. Acta Palaeontologica Romaniae, 4, 203-215.

Leuteritz, T. E. J., \& Gantz, D. T. (2013). Sexual dimorphism in Radiated Tortoises (Astrochelys radiata). Chelonian Research Monographs, 6, 105-112. doi: 10.3854/ crm.6.a18p105

Limaverde, S., Pêgas, R. V., Damasceno, R., Villa, C., Oliveira, G., Bonde, N., \& Leal, M. E. C. (2020). Interpreting character variation in turtles: Araripemys barretoi (Pleurodira: Pelomedusoides) from the Araripe Basin, Early Cretaceous of Northeastern Brazil. PeerJ, 6:e27262v1. doi: 10.7287/peerj.preprints.27262v1

Mikan J. C. (1825). Delectus Florae et Faunae Brasiliensis. Fasciculus Quartus. A. Strauss.

Mitteroecker, P., Gunz, P., Windhager, S., \& Schaefer, K. (2013). A brief review of shape, form, and allometry in geometric morphometrics, with applications to human facial morphology. Hystrix, the Italian Journal of Mammalogy, 24(1), 59-66. doi: 10.4404/ hystrix-24.1-6369 
Páez, V. P., Morales-Betancourt, M. A., Lasso, C. A., Castaño-Mora, O. V., \& Bock, B. C. (2012). V. Biología y conservación de las tortugas continentales de Colombia. Serie Editorial Recursos Hidrobiológicos y Pesqueros Continentales de Colombia. Instituto de Investigación de Recursos Biológicos Alexander von Humboldt (IAvH), Colombia.

Páez, V. P., Restrepo, A., Vargas Ramírez, M., Bock, B. C., \& Gallego García, N. (2013). Podocnemis lewyana (Duméril 1852). Tortuga del río Magdalena, tortuga de río. Asociación Colombiana de Herpetología, 1(1), 1-5.

Pereda Suberbiola, X., Corral, J. C., Astibia, H., Badiola, A., Bardet, N., Berreteaga, A., Buffetaut, E., Buscalioni, A. D., Cappetta, H., Cavin, L., Díez Díaz, V., Gheerbrant, E., Murelaga, X., Ortega, F., Pérez-García, A., Poyato, F., Rage, J.-C., Sanz, J. L., \& Torices, A. (2015). Late Cretaceous continental and marine vertebrate assemblages from the Laño quarry (Basque-Cantabrian Region, Iberian Peninsula): an update. Journal of Iberian Geology, 41(1), 101-124. doi: 10.5209/rev jige.2015. v41.n1.48658

Pérez-García, A. (2016). Anew turtle taxon (Podocnemidoidea, Bothremydidae) reveals the oldest known dispersal event of the crown Pleurodira from Gondwana to Laurasia. Journal of Systematic Palaeontology, 15(9), 709-731. doi: 10.1080/14772019.2016.1228549

Pérez-García, A. (2017). The Iberian fossil record of turtles: an update. Journal of Iberian Geology, 43(2), 155-191. doi: 10.1007/s41513-017-0016-4

Pérez-García, A., Scheyer, T. M., \& Murelaga, X. (2012). New interpretations of Dortoka vasconica Lapparent de Broin and Murelaga, a freshwater turtle with an unusual carapace. Cretaceous Research, 36, 151-161. doi: 10.1016/j.cretres.2012.03.006

Pérez-García, A., Gasulla, J. M., \& Ortega, F. (2014). Eodortoka morellana gen. et sp. nov., the first panpleurodiran turtle (Dortokidae) defined in the Lower Cretaceous of Europe. Cretaceous Research, 48, 130138. doi: 10.1016/j.cretres.2013.12.004

Pérez-García, A., Ortega, F., Bolet, A., Escaso, F., Houssaye, A., Martínez-Salanova, J., de Miguel Chaves, C., Mocho, P., Narváez, I., Segura, M., Torices, A., Vidal, D., \& Sanz, J. L. (2016). A review of the upper Campanian vertebrate site of Armuña (Segovia Province, Spain). Cretaceous Research, 57, 591-623. doi: 10.1016/j. cretres.2015.08.008

Price, I. L. (1973). Quelônio Amphichelydia no Cretáceo Inferior do Nordeste do Brasil. Revista Brasileira de Geociências, 3, 84-96.

Pritchard, P. C. H. (1979). Encyclopedia of Turtles. T. F. H. Publications, Inc.

Pritchard, P. C. H. (2008). Evolution and structure of the turtle shell. In J. Wyneken, M. H. Godfrey, \& V. Bels (Eds.), Biology of turtles (pp. 46-83). CRC Press.

R Core Team (2020). R: A language and environment for statistical computing. R Foundation for Statistical Computing, Vienna, Austria.

Regis, K. W., \& Meik, J. M. (2017). Allometry of sexual size dimorphism in turtles: a comparison of mass and length data. PeerJ, 5:e2914.

Rohlf, F. J. (2010a). Relative Warps Version 1.49. State University of New York at Stony Brook.

Rohlf, F. J. (2010b). tpsDig v. 2.16. State University of New York at Stony Brook.
Rohlf, F. J. (2015). The tps series of software. Hystrix, the Italian Journal of Mammalogy, 26(1), 9-12.

Rohlf, F. J., \& Slice, D. (1990). Extensions of the Procrustes method for the optimal superimposition of landmarks. Systematic Zoology, 39(1), 40-59. doi: 10.2307/2992207

Schleich, H. H. (1990). Neues material zu Araripemys barretoi Price 1973 (Testudines: Pleurodira). Mitteilungen der Bayerischen Staatssammlung für Paläontologie und Historische Geologie, 30, 39-49.

Schweigger, A. F. 1812. Prodromus monographiae Cheloniorum. Königsberger Archiv für Naturwissenschaft und Mathematik, 1, 271-462.

Sepúlveda-Seguro, A. M., Páez, V. P., Gómez-Rincón, M. T., Morales-Betancourt, M. A., \& Lasso, C. A. (2020). Evaluación de las características de las poblaciones y el uso de los hábitats de Podocnemis vogli (Müller 1935) durante una temporada reproductiva en la reserva natural privada de Bojonawi (Departamento de Vichada, Colombia). Revista Latinoamericana de Herpetología, 3(2), 83-94.

Shaw, G. (1794). The Zoology of New Holland. British Museum of Natural History.

Strydom, A. V. (2001). Seasonal Reproduction and Sexual Size Dimorphism of the African Helmeted Turtle, Pelomedusa subrufa (Family Pelomedusidae). (PhD Thesis, University of Stellenbosch, South Africa).

Sullivan, P. M., \& Joyce, W. G. (2017). The shell and pelvic anatomy of the Late Jurassic turtle Platychelys oberndorferi based on material from Solothurn, Switzerland. Swiss Journal of Palaeontology, 136(2), 323-343. doi: 10.1007/s13358-017-0136-7

Szczygielski, T., Slowiak, J., \& Dróżdż, D. (2018). Shell variability in the stem turtles Proterochersis spp. PeerJ, 6:e6134. doi: 10.7717/peerj.6134

Trembath, D., \& Freier, D. (2004). Sexual-size dimorphism in Emydura krefftii (Testudines: chelidae) from Ross River, Townsville, Australia. Herpetological Review, 35(1), 31-34.

Troschel, F. H. (1848). Amphibien. In R. Schomburgk (Ed.), Reisen in Britisch-Guiana in den Jahren 1840-1844. Dritter Theil. Versuch einer Fauna und Flora von BritischGuiana (pp. 645-661). Verlagsbuchhandlung J. J. Weber.

Van Dijk, P. P., Iverson, J. B., Rhodin, A. G. J., Schaffer, H. B., \& Bour, R. (2014). Turtles of the World, 7th edition: Annotated checklist of taxonomy, synonymy, distribution with maps, and conservation status. In A. G. J. Rhodin, P. C. H. Pritchard, P. P. van Dijk, R.A. Saumure, K. A. Buhlmann, J. B. Iverson, \& R. A. Mittermeier (Eds.), Conservation biology of freshwater turtles and tortoises: A compilation project of the IUCN/SSC Tortoise and Freshwater Turtle Specialist Group (pp. 329-479). Chelonian Research Foundation.

Vetter, H. (2011). Turtles of the World. Vol. 1. Africa, Europe and Western Asia/Schildkröten der Welt Band 1. Afrika, Europa und Westasien. Edition Chimaira.

Vetter, H., \& Thomson, S. (2007). Turtles of the World. Vol. 5. Australia and Oceania/Schildkröten der Welt Band 5. Australien und Ozeanien. Edition Chimaira.

Wagler, J. G. (1830a). Natürliches System der Amphibien, mit vorangehender Classification der Säugthiere und Vögel. Ein Beitrag zur vergleichenden Zoologie.

Wagler, J. G. (1830b). Natürliches System der Amphibien, mit vorangehender Classification der Säugthiere und Vögel. Ein Beitrag zur vergleichenden Zoologie. 
Wagner, A. (1853). Beschreibung einer fossilen Schildkröten und etlicher anderer Reptilien-Überreste aus den lithographischen Schiefern und dem grünen Sandsteine von Kehlheim. Abhandlungen der Bayerischen Akademie der Wissenschaften, mathematisch-physikalische Klasse, 7, 241-264.
Zelditch, M. L., Swiderski, D. L., \& Sheets, H. D. (2012). A Practical Companion to Geometric Morphometrics for Biologists: Running analyses in freely-available software. Academic Press. 